\title{
MANAJEMEN PEMUPUKAN N-P-K DENGAN PUPUK HAYATI UNTUK MEMPERTAHANKAN KANDUNGAN N DAN P TANAH SERTA HASIL KEDELAI
}

\section{FERTILIZER MANAGEMENT OF N-P-K WITH BIOFERTILIZER FOR RETAINING SOIL NITROGEN AND PHOSFOR CONTENT AND CROPS OF SOYBEAN}

\author{
Emma Trinurani Sofyan ${ }^{1}$ dan Stefina Liana Sari ${ }^{2}$ \\ ${ }^{1}$ Departemen Ilmu Tanah dan Manajemen Sumberdaya Lahan \\ ${ }^{2}$ Pascasarjana Jurusan IImu Tanah dan Manajemen Sumberdaya Lahan \\ Fakultas Pertanian Universitas Padjadjaran \\ Jl Jatinangor-Sumedang Km. 21 Jatinangor, 45363 \\ Korespondensi : emma_trinurani@yahoo.com
}

Diterima 21 Februari 2017 / Disetujui 29 Juli 2017

\begin{abstract}
ABSTRAK
Salah satu upaya untuk meningkatkan produktivitas kedelai pada Inceptisols Jatinangor ialah dengan memanfaatkan inokulan mikroorganisme tanah seperti bakteri pemfiksasi nitrogen dan pelarut fosfat dalam bentuk pupuk hayati khusus kedelai tanpa meninggalkan pupuk anorganik sebagai sumber hara tersedia untuk tanaman. Penelitian ini bertujuan mengetahui pengaruh manajemen pemupukan N-P-K dengan pupuk hayati dalam mempertahankan kandungan hara $\mathrm{N}$ dan $\mathrm{P}$ serta hasil kedelai. Penelitian dilaksanakan pada bulan April hingga Juli 2016, disusun dengan Rancangan Acak Kelompok (RAK) sederhana yang terdiri dari 10 perlakuan. Kombinasi perlakuan N-P-K dengan pupuk hayati sebagai berikut $A=$ Kontrol (tanpa pupuk), B $=\mathrm{N}-\mathrm{P}-\mathrm{K}$ Standar, $\mathrm{C}=1 \mathrm{PHKK}+0 \mathrm{~N}-\mathrm{P}-\mathrm{K}, \mathrm{D}=1 / 4 \mathrm{~N}-\mathrm{P}-\mathrm{K}+1 \mathrm{PHKK}, \mathrm{E}=1 / 2$ N-P-K + 1 PHKK, F = 3/4 N-P-K + 1 PHKK, G = 1 N-P-K + 1 PHKK, H = 3/4 + 1/4 PHKK, I = 3/4 N-P-K $+1 / 2$ PHKK dan $\mathrm{J}=3 / 4 \mathrm{~N}-\mathrm{P}-\mathrm{K}+3 / 4$ PHKK. Hasil penelitian menunjukkan dosis pupuk hayati dengan N-P-K yang dianjurkan ialah perlakuan E yaitu 1 PPHK $\left(250 \mathrm{~kg} \mathrm{ha}^{-1}\right)$ bersama $1 / 2 \mathrm{~N}-\mathrm{P}-\mathrm{K}$ $\left(37,5-50-50 \mathrm{~kg} \mathrm{ha}^{-1}\right)$. Dosis tersebut mampu meningkatkan kandungn nitrogen dan fosfor tanah, tanaman, serta hasil kedelai dengan peningkatan hasil sebesar $0,4 \mathrm{t} \mathrm{ha}^{-1}$ atau $32 \%$ dari N-P-K standar.
\end{abstract}

Kata kunci : kedelai, N-P-K, pupuk Hayati.

\begin{abstract}
One effort to increase the productivity of soybeans in Inceptisols Jatinangor is through utilize inoculant of soil microorganisms such as nitrogen-fixing bacteria and phosphatesolubilizing bacteria in the form of specific biofertilizer (SB) for soybean plant without leaving inorganic fertilizer as a source of available nutrients to plants. This research aimed to determine fertilization management of N-P-K and specific biofertilizer in retaining $\mathrm{N}$ and $\mathrm{P}$ availability and yield of soybean. The Research was conducted from April to July 2016, arranged in Simple Randomized Block Design (RBD) and consisted of 10 treatments. The combination of biofertilizer and N-P-K were as follows; $A=$ control (without fertilizer), $\mathrm{B}=$
\end{abstract}


Standard N-P-K, C $=0 \mathrm{~N}-\mathrm{P}-\mathrm{K}+1 \mathrm{SB}, \mathrm{D}=1 / 4 \mathrm{~N}-\mathrm{P}-\mathrm{K}+1 \mathrm{SB}, \mathrm{E}=1 / 2 \mathrm{~N}-\mathrm{P}-\mathrm{K}+1 \mathrm{SB}, \mathrm{F}=3 / 4 \mathrm{~N}-\mathrm{P}-\mathrm{K}+1$ $\mathrm{SB}, \mathrm{G}=1 \mathrm{~N}-\mathrm{P}-\mathrm{K}+1 \mathrm{SB}, \mathrm{H}=3 / 4+1 / 4 \mathrm{SB}, \mathrm{I}=3 / 4 \mathrm{~N}-\mathrm{P}-\mathrm{K}+1 / 2 \mathrm{SB}$ dan $\mathrm{J}=3 / 4 \mathrm{~N}-\mathrm{P}-\mathrm{K}+3 / 4 \mathrm{SB}$. The results showed a dose of N-P-K and biofertilizer was recommended in the treatment $E$ ( $250 \mathrm{~kg}$ $\left.\mathrm{ha}^{-1} \mathrm{SB}\right)$ and $1 / 2 \mathrm{~N}-\mathrm{P}-\mathrm{K}\left(37.5-50-50 \mathrm{~kg} \mathrm{ha}^{-1}\right)$. The dose was able to increase nitrogen and phosphor content in soil and plant, also on yield of soybean up to $0.4 \mathrm{t} \mathrm{ha}^{-1}$ or $32 \%$ of a standard N-P-K.

Key words: biological fertilizer, N-P-K, soybean

\section{PENDAHULUAN}

Bahan pangan dari famili leguminoseae yang banyak dikonsumsi oleh penduduk Indonesia salah satunya adalah kedelai (Glycine max (L.) Merr.). Konsumsi kedelai nasional dihitung berdasarkan jumlah penduduk dan konsumsi per kapita per tahun. Jumlah penduduk tumbuh sekitar 1,3\% per tahun, konsumsi kedelai dalam negeri sebesar 35\% dipenuhi dari kedelai impor (Departemen Pertanian, 2008; Aldillah, 2014). Pada tahun 2010 produksi kedelai diperkirakan sebesar 927,38 ribu ton biji kering, menurun sebanyak 47,13 ribu ton (4,84\%) dibandingkan tahun 2009 (BPS, 2010). Berdasarkan data yang diperoleh dari BPS dan Kementerian Pertanian menunjukkan bahwa capaian produksi kedelai tahun 2010-2012 terjadi penurunan berturut-turut sebanyak 0,91 juta ton, 0,85 juta ton, dan 0,84 juta ton (Bappenas, 2013).

Tingginya konsumsi dan menurunnya produksi komoditas kedelai di Indonesia perlu penanganan yang baik dan berkelanjutan agar hasil dapat ditingkatkan kembali. Peningkatan hasil kedelai dapat dilakukan dengan menyediakan hara yang cukup agar tanaman dapat tumbuh dengan baik. Penyediaan hara erat kaitannya dengan pemupukan. Manajemen pemupukan menjadi usaha yang penting untuk meningkatkan pertumbuhan dan produksi tanaman serta mengganti kehilangan berbagai unsur hara dalam hal ini nitrogen (N) dan fosfor (P). Disamping itu, upaya untuk meningkatkan produktivitas kedelai pada Inceptisols Jatinangor ialah dengan memanfaatkan inokulan mikroorganisme tanah seperti bakteri pemfiksasi nitrogen dan pelarut fosfat dalam bentuk pupuk hayati tanpa meninggalkan pupuk anorganik (N-P-K) sebagai sumber hara tersedia untuk tanaman.

Pemanfaatan pupuk hayati khusus tanaman kedelai (PHKK) mendampingi pupuk N-P-K menjadi salah satu alternatifnya. Mikroorganisme dalam pupuk hayati dapat terus membantu dalam pelarutan hara bagi tanaman, sedangkan pupuk anorganik berperan sebagai pensuplai hara tersedia. Bakteri pemfiksasi N dalam PHKK mampu menyediakan unsur hara $\mathrm{N}$ yang merupakan penyusun dari banyak senyawa bagi tanaman seperti asam amino yang diperlukan untuk pembentukan protein dan enzim (Lakitan, 1995). Besarnya nilai $\mathrm{N}$ yang berasal dari fiksasi simbiosis pada tanaman kedelai adalah sekitar 50\% (Fabre dan Planchon, 2000). Peningkatan fiksasi N terjadi pada akhir berbunga dan selama periode pengisian biji (Fabre dan Planchon, 2000).

Pelarut $\mathrm{P}$ dalam hal ini membantu proses pelarutan hara $\mathrm{P}$ yang merupakan komponen senyawa ATP (adenosin trifosfat) yang berfungsi sebagai sumber energi untuk 
pertumbuhan tanaman serta penyusun DNA (asam deosiribonukleat) dan RNA (asam ribonukleat) yang penting dalam pembelahan sel dan reproduksi (Taufiq, 2014). Menurut Herrera et al. (2016), pertumbuhan dan hasil akan semakin meningkat apabila protein dan enzim yang dihasilkan semakin banyak, karena protein dan enzim adalah bahan baku untuk pembentukan sel-sel baru yang akan mempercepat pertumbuhan sehingga diharapkan produksi tanaman kedelai menjadi meningkat.

Ketersediaan hara $\mathrm{N}$ dan $\mathrm{P}$ pada tanah mineral Inceptisols Jatinangor masih rendah hingga sedang. Sehingga manajemen pemupukan terutama pemanfaatan pupuk hayati khusus kedelai (PHKK) dengan pupuk anorganik (N-P-K) pada Inceptisols Jatinangor ini khususnya, penting agar ketersediaan hara essensial pada tanah Inceptisols yang kurang ini menjadi terpenuhi untuk selanjutnya dapat meningkatkan produksi dan produktivitas kedelai.

\section{BAHAN DAN METODE}

Percobaan dilaksanakan pada bulan April hingga Juli 2016 di lahan kering Kebun Percobaan Pengelolaan Tanah dan Air serta di Laboratorium Kesuburan Tanah dan Nutrisi Tanaman Fakultas Pertanian Unpad, Jatinangor, ketinggian $725 \mathrm{mdpl}$. Alat dan bahan meliputi seperangkat peralatan lapangan mulai dari sampling hingga panen, tanah Inceptisols Jatinangor, benih kedelai varietas Arjasari serta bahan kimia laboratorium untuk analisis kimia.

Percobaan menggunakan rancangan acak kelompok (RAK) sederhana, sepuluh perlakuan dengan tiga ulangan. Menejemen pemupukan dibuat dengan mengkombinasikan pupuk N-P-K standar dengan Pupuk Hayati Khusus Kedelai (PHKK) yang mengandung mikroba pemfiksasi $\mathrm{N}$ dan pelarut $P$ sebagai berikut. $A=\operatorname{Kontrol}(0 \mathrm{~N}$ $\mathrm{P}-\mathrm{K}+0 \mathrm{~kg} \mathrm{ha}^{-1}$ PHKK), B = N-P-K Standar (75100-100 kg ha-1 $), C=0$ N-P-K (0-0-0 kg ha-1) + 1 PHKK $\left(250 \mathrm{~kg} \mathrm{ha}^{-1}\right), \mathrm{D}=1 / 4 \mathrm{~N}-\mathrm{P}-\mathrm{K}(18,75-$ $\left.25-25 \mathrm{~kg} \mathrm{ha}^{-1}\right)+1$ PHKK $\left(250 \mathrm{~kg} \mathrm{ha}^{-1}\right), \mathrm{E}=1 / 2$ N-P-K (37,5-50-50 kg ha $\left.{ }^{-1}\right)+1$ PHKK $(250 \mathrm{~kg}$ $\left.\mathrm{ha}^{-1}\right), \mathrm{F}=3 / 4 \mathrm{~N}-\mathrm{P}-\mathrm{K}\left(56,25-75-75 \mathrm{~kg} \mathrm{ha}^{-1}\right)+1$ PHKK (250 kg ha-1), G = 1 N-P-K (75-100-100 $\left.\mathrm{kg} \mathrm{ha}^{-1}\right)+1$ PHKK $\left(250 \mathrm{~kg} \mathrm{ha}^{-1}\right), \mathrm{H}=3 / 4 \mathrm{~N}-\mathrm{P}-$ $\mathrm{K}\left(56,25-75-75 \mathrm{~kg} \mathrm{ha}^{-1}\right)+1 / 4$ PHKK $(62,5 \mathrm{~kg}$ $\left.\mathrm{ha}^{-1}\right), \mathrm{I}=3 / 4 \mathrm{~N}-\mathrm{P}-\mathrm{K}\left(56,25-75-75 \mathrm{~kg} \mathrm{ha}^{-1}\right)+$ 1/2 PHKK $125\left(\mathrm{~kg} \mathrm{ha}^{-1}\right)$ dan J = 3/4 N-P-K (56,25-75-75 kg ha $\left.{ }^{-1}\right)+3 / 4$ PHKK $(187,5 \mathrm{~kg}$ $\left.\mathrm{ha}^{-1}\right)$. Setiap perlakuan diulang 3 kali sehingga total unit percobaan berjumlah 30 dan pada setiap unit percobaan terdiri atas 2 tanaman, yang merupakan sampel pengamatan hingga destruksi dan sampel yang diamati hingga panen.

Pelaksanaan percobaan terdiri atas persiapan benih, persiapan media tanam, penanaman, pemeliharaan, pengambilan sampel dan panen. Teknik budidaya mengikuti cara konvensional yang biasa dilakukan petani kedelai Jatinangor. Pupuk dasar yang digunakan adalah pupuk kandang dengan takaran sebanyak $10 \mathrm{t} \mathrm{ha}^{-1}$ atau setara dengan $50 \mathrm{~g}$ per polibag sebelum penanaman (Syamsiah et al., 2013).

Pengambilan data vegetatif dilakukan setiap minggu, dan pengambilan sampel untuk analisis kandungan hara tanah dilakukan pada vegetatif maksimum dimana tanaman menyerap unsur hara dalam keadaan maksimum. Data yang diperoleh selanjutnya diolah menggunakan software statistik SPSS melalui uji $F$ untuk mengetahui adanya perbedaan respons 
setelah perlakuan diberikan. Apabila terdapat beda nyata maka pengujian dilanjutkan dengan uji lanjut jarak Berganda Duncan pada taraf $5 \%$.

\section{HASIL DAN PEMBAHASAN}

\section{Analisis Tanah Awal Inceptisols}

Hasil analisis laboratorium, menunjukkan bahwa sifat kimia tanah Inceptisols Jatinangor adalah sebagai berikut seperti pada Tabel 1. Kandungan N-total dan Ppotensial tanah berada pada kriteria sedang dan P-tersedia rendah, sehingga inokulan penambat $\mathrm{N}$ dan pelarut fosfat dalam Pupuk Hayati Khusus Kedelai (PHKK) ini dapat dimanfaatkan untuk meningkatkan kelarutan $\mathrm{N}$ dan $\mathrm{P}$ tanah serta dalam meningkatkan serapan hara tersebut oleh tanaman.

Tabel 1. Hasil Analisis Tanah Awal Inceptisols Jatinangor

\begin{tabular}{|c|c|c|c|c|}
\hline No. & Parameter & Satuan & Nilai & Kriteria \\
\hline 1. & $\mathrm{pH} \mathrm{H}_{2} \mathrm{O}(1: 2,5)$ & & 6,32 & Agak masam \\
\hline 2. & $\begin{array}{l}\mathrm{pH} \mathrm{KCl} 1 \mathrm{~N} \\
(1: 2,5)\end{array}$ & & 5,02 & Agak masam \\
\hline 3. & C Organik & $\%$ & 1,86 & Rendah \\
\hline 4. & N Total & $\%$ & 0,38 & Sedang \\
\hline 5. & Rasio $\mathrm{C} / \mathrm{N}$ & & 7 & Rendah \\
\hline 6. & $\mathrm{P}_{2} \mathrm{O}_{5}$ Bray I & $\mathrm{mg} \mathrm{kg}^{-1}$ & 6,41 & Sedang \\
\hline 7. & $\mathrm{P}_{2} \mathrm{O}_{5} \mathrm{HCl} 25 \%$ & mg $100 g^{-1}$ & 39,27 & Sedang \\
\hline 8. & $\mathrm{~K}_{2} \mathrm{O} \mathrm{HCl} 25 \%$ & $\mathrm{mg} 100 \mathrm{~g}^{-1}$ & 25,38 & Sedang \\
\hline 9. & $\begin{array}{l}\text { Kapasitas } \\
\text { Tukar Kation }\end{array}$ & $\mathrm{cmol} \mathrm{kg}^{-1}$ & 33,6 & Tinggi \\
\hline \multirow[t]{5}{*}{10.} & Susunan Kation : & & & \\
\hline & K-dd & $\mathrm{cmol} \mathrm{kg}^{-1}$ & 0,92 & Tinggi \\
\hline & $\mathrm{Na}-\mathrm{dd}$ & $\mathrm{cmol} \mathrm{kg}^{-1}$ & 0,34 & Rendah \\
\hline & Ca-dd & $\mathrm{cmol} \mathrm{kg}^{-1}$ & 10,67 & Tinggi \\
\hline & Mg-dd & $\mathrm{cmol} \mathrm{kg}^{-1}$ & 9,31 & Sangat tinggi \\
\hline 11. & Kejenuhan Basa & $\%$ & 63,21 & Tinggi \\
\hline 12. & $A l^{3+} d d$ & $\mathrm{cmol} \mathrm{kg}^{-1}$ & 0 & \\
\hline 13. & $\mathrm{H}^{+} \mathrm{dd}$ & $\mathrm{cmol} \mathrm{kg}^{-1}$ & 0,55 & \\
\hline 14. & Kejenuhan Al & $\%$ & 0,55 & \\
\hline \multirow[t]{4}{*}{15.} & Tekstur: & & & \\
\hline & Pasir & $\%$ & 8 & \\
\hline & Debu & $\%$ & 41 & Liat berdebu \\
\hline & Liat & $\%$ & 51 & \\
\hline
\end{tabular}

Sumber : Lab kesuburan Tanah dan Nutrisi Tanaman Fakultas Pertanian Unpad (2016)

\section{Kandungan Hara $\mathbf{N}$ dan $\mathbf{P}$ Tanah}

Pemberian PHKK bersama pupuk N-P-K menyebabkan perbedaan persentase kandungan $\mathrm{N}$-total tanah. Hal ini dapat dilihat pada Gambar 1.

Kandungan $\mathrm{N}$-total tanah yang meningkat secara signifikan berturut-turut yaitu pada perlakuan E, H, J dan B. Nasikah (2007) menyatakan nitrogen di atmosfer dapat berupa Urea $\mathrm{CO}\left(\mathrm{NH}_{2}\right)_{2} ; \mathrm{N}_{2}$ dan $\mathrm{N}$. Akan tetapi, tidak ada yang secara langsung dapat digunakan oleh tanaman. Nitrogen memasuki tanah dalam bentuk ammonia dan nitrat $\left(\mathrm{NH}_{3}\right)$ bersama air hujan, dalam 
bentuk hasil penambatan $\mathrm{N}_{2}$ oleh mikroba atau dalam bentuk penambahan pupuk sintesis.

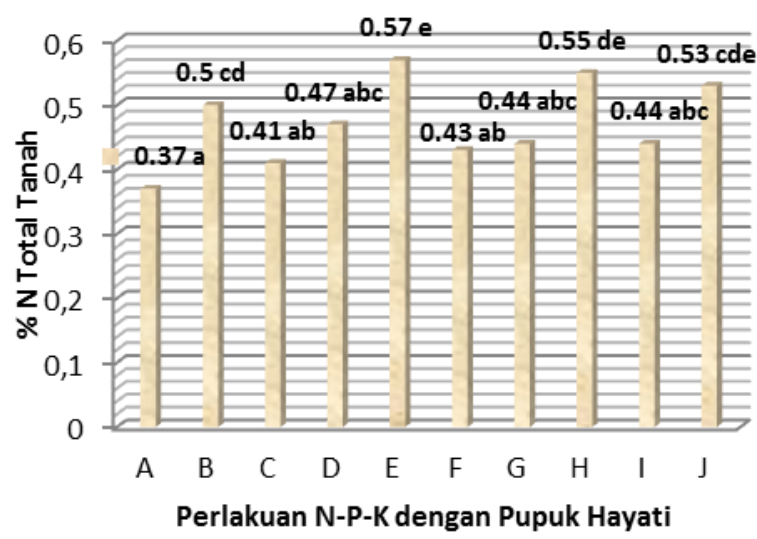

Gambar 1. Diagram Batang Kandungan N-Total Tanah pada Vegetatif Maksimum pada Berbagai Perlakuan

Kandungan $\mathrm{N}$-total tertinggi ialah pada perlakuan E. Kandungan nitrogen tanah yang cukup tinggi lebih banyak disebabkan oleh adanya kemampuan beberapa mikroba untuk memfiksasinya. Salah satu mikroba penambat $\mathrm{N}$ ini terdapat dalam PHKK. Senyawa N organik yang terbentuk diubah menjadi ammonia melalui proses deaminasi, karena ammonia dapat secara langsung diasimilasikan oleh mikroba atau diubah terlebih dahulu menjadi senyawa nitrat melalui nitrifikasi (Nasikah, 2007). Oleh karena itu pengurangan dosis N-P-K pada berbagai perlakuan di atas yang disertai aplikasi PHKK dapat mempertahankan kandungan $\mathrm{N}$-total tanah yang hampir sama dengan perlakuan N-P-K standar.

Pengaruh manajemen pemupukan N-P-K dengan pupuk hayati terhadap kandungan $P$ tanah, baik kandungan potensial dan $P$ tersedia dapat meningkat secara signifikan. Perlakuan E atau 1/2 dosis N-P-K (37,5-50$50 \mathrm{~kg} \mathrm{ha}^{-1}$ ) dengan 1 PHKK (250 kg ha ${ }^{-1}$ ) meningkatkan kandungan $\mathrm{P}$ potensial dan $\mathrm{P}$ tersdia tanah tertinggi. Data lengkap setiap perlakuan dapat dilihat pada Gambar 2 dan 3 berikut ini.

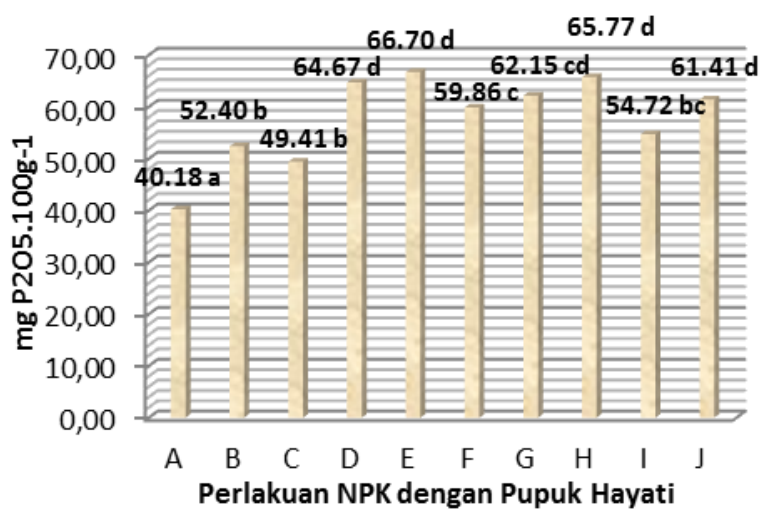

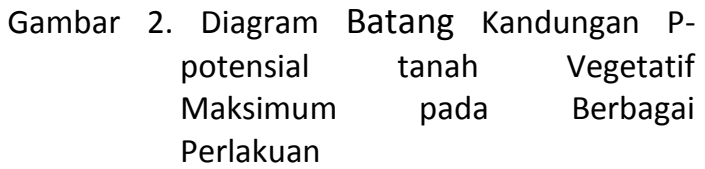

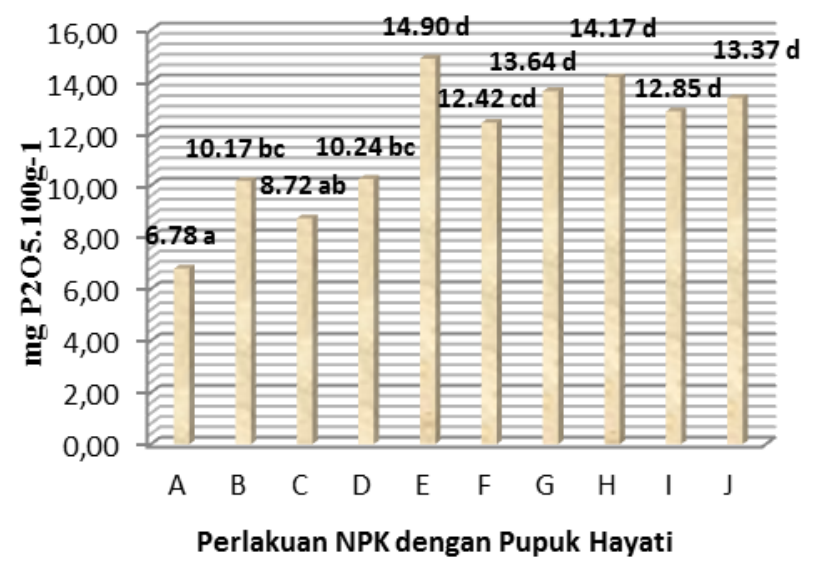

Gambar 3. Diagram Batang Kandungan Ptersedia tanah Vegetatif Maksimum pada Berbagai Perlakuan

Keterangan : $A=$ Kontrol $B=N-P-K$ Standar, $C=0$ $\mathrm{N}-\mathrm{P}-\mathrm{K}+1, \mathrm{D}=1 / 4 \mathrm{~N}-\mathrm{P}-\mathrm{K}+1 \mathrm{PHKK}, \mathrm{E}=1 / 2 \mathrm{~N}-\mathrm{P}-$ $\mathrm{K}+1$ PHKK, F= 3/4 N-P-K +1 PHKK, G= $1 \mathrm{~N}-\mathrm{P}-\mathrm{K}+1$ PHKK, H= 3/4 N-P-K + 1/4 PHKK, I= 3/4 N-P-K + 1/2 PHKK 125 dan J= 3/4 N-P-K + 3/4 PHKK 
Kandungan P-potensial setelah aplikasi PHKK dengan N-P-K menunjukkan hasil berbeda nyata dengan perlakuan kontrol dan beberapa diantaranya berbeda nyata dengan dosis N-P-K standar. P-potensial tertinggi ditunjukkan oleh perlakuan $\mathrm{E}$ yang tidak berbeda nyata terhadap perlakuan $D$, G, H dan J. Kandungan P-potensial meningkat akibat penambahan pupuk anorganik, yang semula pada analisis tanah awal diketahui pada kisaran 39,27 mg $\mathrm{P}_{2} \mathrm{O}_{5}$ $100 \mathrm{~g}^{-1}$ atau pada perlakuan kntrol 40,18 mg $\mathrm{P}_{2} \mathrm{O}_{5} 100 \mathrm{~g}^{-1}$ yang berada pada kategori sedang, meningkat hingga melebihi $60 \mathrm{mg}$ $\mathrm{P}_{2} \mathrm{O}_{5} 100 \mathrm{~g}^{-1}$ atau kriteria sangat tinggi.

Peningkatan P Potensial pada beberapa perlakuan ini disebabkan oleh pengaruh langsung dari pemupukan $\mathrm{P}$ dengan dosis yang optimal, kombinasi dosis pupuk N-P-K dengan PHKK yang diberikan akan lebih efektif meningatkan $P$ dalam tanah. Hal ini sejalan dengan Suyono et al. (2006), yang menyatakan bahwa pertambahan $\mathrm{P}$ di dalam tanah salah satunya dari pupuk fosfat.

Fosfor di dalam tanah terdapat dalam bentuk $\mathrm{H}_{2} \mathrm{PO}_{4}{ }^{-}, \mathrm{HPO}_{4}{ }^{2-}, \mathrm{PO}_{4}{ }^{3}$-, dan dalam bentuk ikatan-ikatan dengan ion logam seperti ion $\mathrm{Fe}, \mathrm{Ca}$, Al dan $\mathrm{Mn}$. Fosfor dinyatakan dalam bentuk oksidanya yaitu $\mathrm{P}_{2} \mathrm{O}_{5}$, yang kemudian akan bereaksi menghasilkan asam fosfat $\left(\mathrm{H}_{3} \mathrm{PO}_{4}\right)$. Asam fosfat yang dihasilkan bereaksi dengan $\mathrm{OH}$ dan membentuk ion $\mathrm{H}_{2} \mathrm{PO}_{4}$. Ion-ion $\mathrm{H}_{2} \mathrm{PO}_{4}$ tersebut akan membentuk ikatan dengan ion logam seperti $\mathrm{Mn}$ dan Fe yang dapat membentuk ikatan dengan $P$ menjadi senyawa yang sukar larut dalam air. Semakin banyak $P$ yang diberikan maka semakin banyak pula $P$ yang diikat oleh koloid tanah, sehingga akan meningkatkan $P$ Potensial tanah.
P Potensial merupakan akumulasi $\mathrm{P}$ yang terlarut dan $\mathrm{P}$ yang tidak terlarut dalam tanah, tapi berpotensi menjadi bentuk tersedia. Pupuk $\mathrm{P}$ yang diberikan memberikan residu yang cukup besar dalam tanah, karena kehilangan $\mathrm{P}$ akibat tercuci, tererosi dan terserap tanaman relatif kecil. Menurut Jones (1982) dalam Elfiati (2005), tanaman memanfaatkan $\mathrm{P}$ hanya sebesar 10\%-30\% dari pupuk $P$ yang diberikan berarti $70 \%-90 \%$ pupuk $P$ tetap berada dalam tanah. Pelarut fosfat dalam PHKK berperan melarutkan $\mathrm{P}$ tanah yang sukar larut menjadi larut dan tersedia bagi tanaman, sisa $P$ tersedia yang tidak termanfaatkan oleh tanaman akan diikat kembali menjadi $\mathrm{P}$ tidak larut atau $\mathrm{P}$ cadangan.

\section{Kandungan Hara N dan P Tanaman Kandungan $\mathbf{N}$ Tanaman}

Gambar 4 dan 5 merupakan hasil analisis kandungan $\mathrm{N}$-total dan P-total pada jaringan tanaman kedelai pada berbagai perlakuan dosis PHKK dengan pupuk anorganik N-P-K. Kandungan N-total pada jaringan tanaman semua perlakuan penambahan PHKK tidak berbeda nyata dengan aplikasi N-P-K standar, namun perlakuan $E$ berbeda nyata dengan perlakuan kontrol (tanpa pupuk).

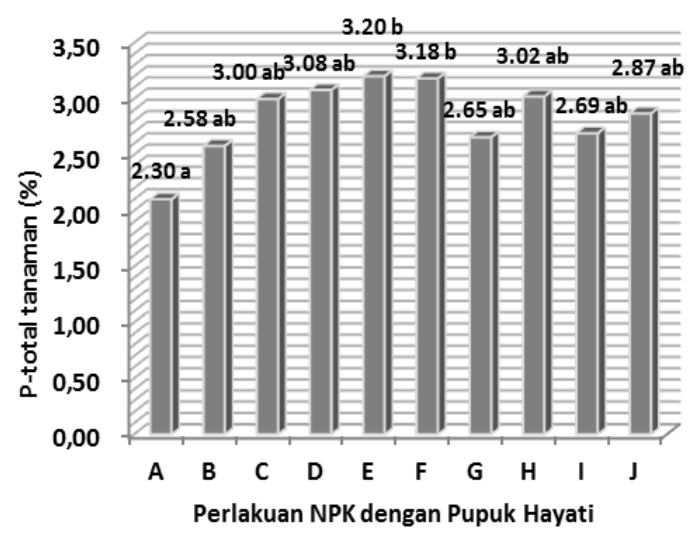

Gambar 4. Diagram Batang Kandungan N-total Tanaman 
Kandungan $\mathrm{N}$-total tanah, tidak selalu berhubungan secara linier dengan penyerapannya oleh tanaman. Nitrogen dalam bentuk tersedia, dalam hal ini yang berasal dari N-P-K dan penambatan $\mathrm{N}$ oleh mikroba dalam PHKK, mudah hilang melalui proses denitrifikasi oleh mikroorganisme menjadi $\mathrm{N}_{2}$ (gas) kembali dan pencucian dalam bentuk ion $\mathrm{NO}_{3}$. Bertambahnya kandungan $\mathrm{N}$-total tanah akibat aplikasi PHKK dalam hal ini ternyata belum mampu meningkatkan penyerapan $\mathrm{N}$ oleh tanaman kedelai secara signifikan. Berikut ini merupakan diagram batang yang menggambarkan pengaruh aplikasi berbagai perlakuan tersebut terhadap $\mathrm{N}$-total jaringan tanaman.

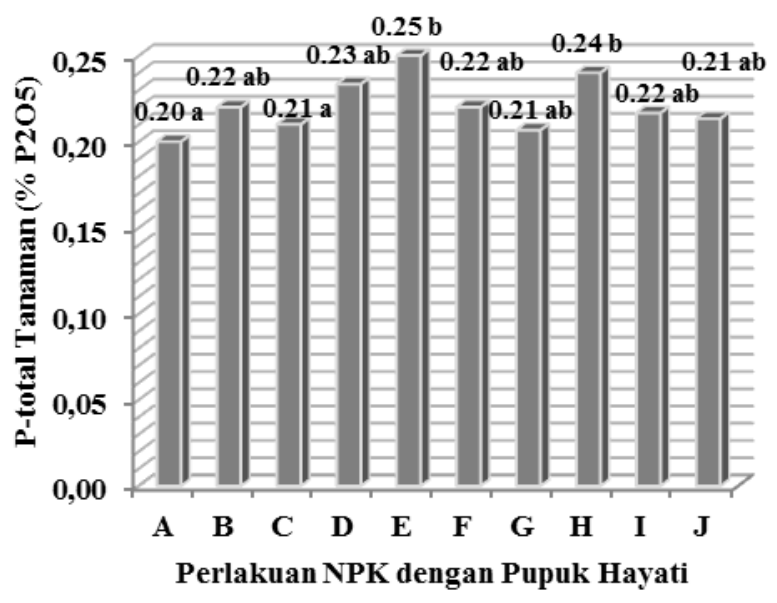

Gambar 5. Diagram Batang Kandungan P-total Tanaman

Analisis statistik menunjukkan bahwa Ppotensial akibat aplikas kombinasi pupuk $\mathrm{N}$ P-K dengan pupuk hayati tidak berbeda nyata dengan perlakuan N-P-K standar, namun hasil tertinggi jika dibandingkan dengan kontrol adalah perlakuan $\mathrm{E}$ dan $\mathrm{H}$ yaitu $1 / 2 \mathrm{~N}-\mathrm{P}-\mathrm{K}+1$ PHKK dan 3/4 N-P-K + 1/4 PHKK.

Beberapa bakteri tanah diantaranya bekteri pelarut fosfat yang terdapat dalam PHKK, dapat mengeluarkan asam-asam organik yang menurunkan $\mathrm{pH}$ di sekitarnya untuk memutuskan ikatan fosfat dalam tanah (Mohan dan Radhakrishnan, 2012). Bakteri-bakteri pelarut fosfat melarutkan unsur fosfat, diantaranya fosfat tersedia dari pupuk yang terikat pada unsur lain ( $\mathrm{Fe}$, $\mathrm{Al}, \mathrm{Ca}$, dan $\mathrm{Mg}$ ), sehingga unsur $\mathrm{P}$ tersebut menjadi tersedia kembali bagi tanaman (Widiawati dan Suliasih, 2006 dalam Marista et al., 2013). Ketersediaan hara yang tinggi memungkinkan penyerapan hara yang tinggi oleh tanaman (Supriyadi et al., 2014).

\section{Hasil Tanaman}

Komponen hasil yang diamati meiputi jumlah polong total per tanaman, termasuk polong isi dan polong hampa, dan bobot 1000 butir biji kedelai. Analisis statistik untuk beberapa komponen hasil pada berbagai kombinasi dosis N-P-K dengan pupuk hayati khusus kedelai adalah sebagai berikut (Tabel 2).

Jumlah polong tertinggi ditunjukkan pada perlakuan $\mathrm{H}$ yaitu dosis $3 / 4 \mathrm{~N}-\mathrm{P}-\mathrm{K}+$ 1/4 PHKK yang diikuti dengan hasil yang tidak berbeda nyata pada perlakuan $D$ dan E. Jumlah polong isi dari perlakuan ini masing masing berturut-turut adaah 61,59 dan 58 polong per tanaman. Jumlah polong total tertinggi pada parlakuan tersebut memiliki jumlah polong isi tertinggi pula dengan hasil analisis statistik bernotasi sama (perbedaan yang tidak signifikan). Hasil ini dapat dijelaskan dengan alasan bahwa N-P-K sebagai sumber hara esensial $\mathrm{N}, \mathrm{P}$ dan $\mathrm{K}$ di samping kandungannya yang tinggi, mudah larut dalam air dan hampir semua yang digolongkan sebagai unsur tersedia.

Menurut Permanasari (2014), tingginya ketersediaan $\mathrm{N}$ dari pupuk anorganik bersama pemanfaatan mikroorganisme pemfiksasi $\mathrm{N}$ meningkatkan hasil kedelai. peningkatan bobot dan ukuran biji 
dipengaruhi oleh besarnya fotosintat yang dihasilkan oleh tanaman untuk didistribusikan ke biji untuk pembesaran biji lebih banyak dibandingkan dengan perlakuan yang memiliki ketersediaan $\mathrm{N}$ rendah. hal ini tentunya berkaitan dengan penyerapan unsur nitrogen yang dilakukan oleh tanaman baik dalam perannya untuk pembentukan klorofil maupun per- tumbuhan ukuran daunnya. Tersedianya unsur $\mathrm{N}$ yang tinggi ini memungkinkan daun yang terbentuk juga akan semakin banyak yang berakibat meningkatnya luas daun tanaman yang meningkatkan akumulasi asimilat yang dihasilkan. menurut Jumin (2008), pertambahan luas daun sangat penting karena pengaruhnya terhadap total produksi bahan kering.

Tabel 2. Komponen Hasil Tanaman Kedelai Akibat Pemupukan PHKK dengan N-P-K

\begin{tabular}{|c|c|c|c|c|c|c|c|c|c|c|c|c|}
\hline \multirow[t]{2}{*}{ Perlakuan } & \multicolumn{2}{|c|}{$\begin{array}{l}\text { Jumlah } \\
\text { polong }\end{array}$} & \multicolumn{2}{|c|}{$\begin{array}{c}\text { Polong } \\
\text { Isi }\end{array}$} & \multicolumn{2}{|c|}{$\begin{array}{l}\text { Polong } \\
\text { hampa }\end{array}$} & \multicolumn{2}{|c|}{$\begin{array}{c}\text { Bobot } 100 \\
\text { butir }\end{array}$} & \multicolumn{2}{|c|}{$\begin{array}{c}\text { Berat } \\
\text { polong } \\
\text { (g) }\end{array}$} & \multicolumn{2}{|c|}{$\begin{array}{c}\text { Berat } \\
\text { polong } \\
\text { (ton) }\end{array}$} \\
\hline & & & & & \multicolumn{4}{|c|}{----- per tanaman ---- } & & & \multicolumn{2}{|c|}{-per ha- } \\
\hline A ; Kontrol & 40 & $a b$ & 21 & $\mathrm{a}$ & 19 & $\mathrm{C}$ & 13.53 & $\mathrm{a}$ & 9.37 & $\mathrm{a}$ & 1.00 & $\mathrm{a}$ \\
\hline $\mathrm{B} ; \mathrm{N}-\mathrm{P}-\mathrm{K}$ standar & 39 & $a b$ & 25 & bc & 14 & $\mathrm{~B}$ & 16.06 & $a b c$ & 11.73 & $b$ & 1.25 & $\mathrm{~b}$ \\
\hline C ; O N-P-K + 1 PHKK & 41 & $a b$ & 22 & $b$ & 19 & $\mathrm{Bc}$ & 15.34 & $a b$ & 11.28 & $a b$ & 1.20 & $a b$ \\
\hline D ; $1 / 4$ N-P-K + 1 PHKK & 59 & $\mathrm{~cd}$ & 50 & $d$ & 9 & $A$ & 20.73 & $c d$ & 14.06 & $\mathrm{~cd}$ & 1.49 & $\mathrm{~cd}$ \\
\hline $\mathrm{E} ; 1 / 2 \mathrm{~N}-\mathrm{P}-\mathrm{K}+1$ PHKK & 58 & $\mathrm{~cd}$ & 48 & $d$ & 10 & $\mathrm{a}$ & & $d$ & 15.53 & $d$ & 1.65 & $d$ \\
\hline F ; 3/4 N-P-K +1 PHKK & 52 & $a b c$ & 44 & bc & 8 & $\mathrm{a}$ & 17.20 & abcd & 14.54 & $\mathrm{~cd}$ & 1.54 & $\mathrm{~cd}$ \\
\hline G ; 1 N-P-K + 1 PHKK & 51 & $a b c$ & 45 & $\mathrm{~cd}$ & 8 & $\mathrm{a}$ & 21.05 & $d$ & 13.05 & bc & 1.39 & bc \\
\hline $\mathrm{H} ; 3 / 4 \mathrm{~N}-\mathrm{P}-\mathrm{K}+1 / 4$ PHKK & 61 & $d$ & 50 & $d$ & 11 & a & 20.91 & $\mathrm{~cd}$ & 13.27 & bc & 1.41 & $\mathrm{bc}$ \\
\hline I ; 3/4 N-P-K + 1/2 PHKK & 48 & $a b c$ & 37 & bc & 11 & $\mathrm{a}$ & 18.75 & bcd & 12.41 & bc & 1.32 & $\mathrm{bc}$ \\
\hline J ; 3/4 N-P-K + 3/4 PHKK & 45 & $a b c$ & 35 & bc & 10 & $\mathrm{a}$ & 17.56 & abcd & 14.23 & $\mathrm{~cd}$ & 1.51 & $\mathrm{~cd}$ \\
\hline
\end{tabular}

Keterangan: Angka rerata yang diikuti huruf yang sama tidak berbeda nyata berdasarkan Uji Jarak Berganda Duncan pada Taraf $5 \%$.

Dalshad et al., (2013) mengemukakan tercukupinya kebutuhan fosfor pada tanah meningkatkan pertumbuhan akar, kemudian meningkatkan pertumbuhan tunas yang selanjutnya meningkatkan komponen hasil tanaman. Pada fase generatif hara $P$ yang tinggi untuk pembentukan biji dan pengisian biji (Supriyadi et al., 2014).

Tabel 2 di atas mengambarkan hasil kedelai per tanaman yang dipanen dan konversinya pada luasan 1 ha. Hasil kedelai per tanaman dan konversinya dalam $\mathrm{t} \mathrm{ha}^{-1}$ yang direkomendasikan adalah perlakuan $\mathrm{E}$ yaitu 1 PHKK (250 kg ha ${ }^{-1}$ ) bersama 1/2 N-P$\mathrm{K}\left(37,5-50-50 \mathrm{~kg} \mathrm{ha}^{-1}\right)$ dengan kenaikan hasil sebesar $32 \%$ dari aplikasi pupuk standar. Dosis lainnya dengan hasil kedelai yang tidak signifikan dengan perlakuan $\mathrm{E}$ diantaranya adalah perlakuan $\mathrm{F}$ dan J. Kedua dosis tersebut merupkan dua diantara kombinasi dosis tertinggi dari aplikasi PHKK dengan N-P-K ini, namun hasil yang tidak signifikan dengan perlakuan pengurangan dosis $\mathrm{N}$ dan $\mathrm{P}$ seperti pada perlakuan $E$ di atas. Dengan kata lain kebutuhan $\mathrm{N}$ dan $\mathrm{P}$ untuk tanaman kedelai yang dibudidayakan pada Inceptisols Jatinagor masih cukup tinggi.

\section{KESIMPULAN}

Berdasarkan percobaan yang telah dilakukan terhadap tanaman kedelai (Glicyne max, L.) varietas Arjasari dapat disimpulkan sebagai berikut: (1) Pengaruh PHKK secara mandiri tanpa pupuk anorganik (N-P-K) serta aplikasi N-P-K standar tanpa 
PHKK belum mampu meningkatkan hasil tanaman kedelai dalam hal ini, peranan PHKK bersifat komplementer menyertai pupuk N-P-K. (2) Pengurangan dosis standar $\mathrm{N}-\mathrm{P}-\mathrm{K}$ pada beberapa perlakuan meskipun dengan penambahan PHKK tidak selalu menunjukkan hasil yang berbeda dengan perlakuan N-P-K standar. (3) Aplikasi PHKK dengan dosis $250 \mathrm{~g} \mathrm{ha}^{-1}$ disertai dengan Urea 37,5 kg ha ${ }^{-1}$, SP-36 $50 \mathrm{~kg} \mathrm{ha}^{-1}$, dan $\mathrm{KCl}$ $50 \mathrm{~kg} \mathrm{ha}{ }^{-1}$ (Perlakuan E) dapat meningkatkan kandungan $\mathrm{N}$ dan $\mathrm{P}$ tanah dan tanaman, serta hasil lebih baik dibandingkan dengan kontrol dan N-P-K standar dengan kenaikan hasil sebesar 32\% dibandingkan N-P-K standar.

\section{DAFTAR PUSTAKA}

Aldillah R. 2014. Proyeksi Produksi dan Konsumsi Kedelai Indonesia. Pusat Analisis Sosial Ekonomi dan Kebijakan Pertanian, Kementrian Pertanian Republik Indonesia.

Badan Pusat Statistik. 2010. Produksi Padi, Jagung, Kedelai (Angka Ramalan III tahun 2010). Berita Resmi Statistik No. 68/II/Th. XIII, 1 November 2010.

Departemen Pertanian. 2008. Mutu Kedelai Nasional Lebih Baik dari Kedelai Impor [Siaran Pers]. Jakarta: Badan Litbang Pertanian.

http://pustaka.litbang.deptan.go.ld/bppi /lengkap/sp1202081.pdf.

Fabre F. dan C. Planchon. 2000. Nitrogen Nutrition, Yield and Protein Content In Soybean. Plant Science 152 (2000) 51-58

Herrera, B., W Ferney., dan M Rodrigues. 2016. Crop Yields and Soil Phosphorus Lability under Soluble and HumicComplexed Phosphate Fertilizers. Agronomy Journal. Vol. 11 No. 6, p. 929931
Jumin, H. B. 2008. Dasar - dasar Agronomi. PT Raja Grafindo Persada. Jakarta. 250 hal.

Mohan, V. dan A. Radhakrishnan. 2012. Screening of phosphate solubilizing bacterial isolates for the growth improvement of Tectona grandis Linn. Research Journal of Microbiology, vol 7, issue 2, hlm. 101- 113.

Nasikah. 2007. Pengaruh Inokulasi Rhizobium dan Waktu Pemberian Pupuk $\mathrm{N}$ (Urea) terhadap Pertumbuhan dan Hasil Kedelai di Lahan Sawah setelah Kedelai (Glycine Max (L) Merril.). Skripsi pada Jurusan Biologi. Fakultas Sains dan Teknologi. Universitas Islam Negeri Malang. Malang.

Permanasari, I., M. Irfan, dan Abizar. 2014. Pertumbuhan dan Hasil Kedelai (Glycine Max (L.) Merill) Dengan Pemberian Rhizobium dan Pupuk Urea pada Media Gambut. Jurnal Agroteknologi, Vol. 5 No. 1, Agustus $2014: 29-34$

Supriyadi, Sri H., dan Almar A.2014. Kajian Pemberian Pupuk $P$, Pupuk Mikro dan Pupuk Organik terhadap Serapan $P$ dan Hasil Kedelai (Glycine Max L.) Varietas Kaba di Inseptisol Gunung Gajah Klaten. Program Studi IImu Tanah, Fakultas Pertanian Universitas Sebelas Maret Surakarta. Jurnal IImu-IImu Pertanian Volume XXIX No. 2.

Syamsiah, M., dan Zean B. 2013. Respon Perkembangan Akar Tanaman Kedelai (Glycine Max. (L) Meril) terhadap Pemberian Pupuk Hayati. Agroscience, 1(3):5-9

Taufiq, A. 2014. Identifikasi Masalah Keharaan Tanaman Kedelai. Balai Penelitian Tanaman Aneka Kacang dan Umbi Badan Penelitian dan Pengembangan Pertanian, Malang 
Jurnal Agro Vol. IV, No. 1, 2017 